\title{
ASOSIASI MAKROZOOBENTOS PADA PADANG LAMUN DI Pantai Merta Segara SANUR, BALI
}

\section{THE ASSOCIATION OF MACROZOOBENTHOS WITH SEAGRASS BEDS IN MERTA SEGARA SANUR, BALI}

\author{
Gede Surya Indrawan ${ }^{1}$, Deny Suhernawan Yusup ${ }^{1}$, DeVi Ulinuha $^{2}$ \\ ${ }^{1}$ Prodi Biologi F. MIPA Universitas Udayana \\ 2 Manajemen Sumberdaya Perairan, FKP Universitas Udayana \\ Email : suryaindrawan89@yahoo.com
}

\section{INTISARI}

Makrozoobentos merupakan salah satu komunitas organisme dasar perairan yang berasosiasi dengan ekosistem lamun. Penelitian ini bertujuan mengetahui asosiasi makrozoobentos dengan kepadatan padang lamun dan tipe sedimen di Pantai Merta Segara. Penelitian dilaksanakan bulan Oktober-Desember 2013 pada waktu surut terendah. Pengambilan sampel dilakukan dengan metode transek kuadrat yang terdiri dari 3 transek dan dibentangkan sepanjang $300 \mathrm{~m}$ dengan interval antar transek $50 \mathrm{~m}$. Hasil penelitian diperoleh Indeks diversitas (H') 4,7 dan Indeks keseragaman (E) 0,85, mengindikasikan bahwa kawasan tersebut tergolong stabil. Jumlah jenis ditemukan 47 jenis dalam 9 kelas, dengan spesies yang mendominansi Eurythoe sp. (Polychaeta), dan nilai indeks dominansi (C) 0,05. Presentase tutupan lamun rata-rata sebesar 51,10 \%, sedangkan tipe sedimen di dominansi oleh koarsa dan pasir kasar. Sebaran makrozoobentos menunjukkan adanya asosiasi dengan kepadatan tutupan lamun dan tipe sedimen gravel.

Kata kunci: asosiasi, makrozoobentos, padang lamun, sedimen

\begin{abstract}
A research on association of macrozoobentos with seagrass beds and sediment types was conducted from October to December 2013 in Merta Segara Beach during low tide. Sampling was carried out along three line transect - each $300 \mathrm{~m}$ long with $50 \mathrm{~m}$ interval. This study observed 47 species with 9 classes where the most dominant species was Eurythoe sp (Polychaeta). The indeks of H' was 4.7, E was 0.85, and C was 0.05. Seagrass percentage coverage was $51.10 \%$, and the type of sediments was dominated by koarse and mix of coarse-sand. It can be conclude that conditions of macrozoobenthos communitiy in seagrass bed were relatively stable. The distribution and density of macrozoobenthos seem to associate with seagrass percentage coverage and type of sediments gravel.
\end{abstract}

Keywords: association, macrozoobenthos, seagrass beds, sediment

\section{PENDAHULUAN}

Makrozoobentos merupakan komunitas organisme yang sebagian atau seluruh siklus hidupnya berada di dasar perairan, baik yang merayap, sessil, maupun menggali lubang (Nybakken, 1988). Makrozoobentos mempunyai peranan penting di perairan sebagai bioindikator lingkungan, bioturbasi sedimen, dan pemakan bahan organik (Ira, 2011; Marmita et al., 2013). Makrozoobentos yang hidup pada ekosistem lamun berpengaruh terhadap struktur rantai makanan (Ruswahyuni, 2008). Selain itu, keanekaragaman jenis makrozoobentos di padang lamun dapat menggambarkan kemantapan dan kestabilan dalam ekosistem tersebut (Wijayanti, 2007).

Beragam biota laut memanfaatkan padang lamun sebagai tempat pemijahan, tempat pengasuhan, tempat mencari makan, dan tempat berlindung (Arifin dan Jompa, 2005; Supriadi et al., 2012). Menurut Ira (2011) total bahan organik dan kepadatan tutupan lamun dapat mempengaruhi keberadaan struktur makrozoobentos, kepadatan tutupan lamun yang tinggi memiliki kelimpahan makrozoobentos yang tinggi dibandingkan dengan kepadatan tutupan lamun yang rendah. Sedimen mempunyai peran penting sebagai tingkat kelangsungan hidup dari lamun dan makrozoobentos. Tekstur sedimen dalam perairan mempunyai ukuran bervariasi dari yang besar sampai halus. Perbedaan sedimen ini dapat mempengaruhi ketersediaan oksigen, makanan, sebaran, morfologi fungsional, dan tingkah laku makrozoobentos (Sudaryanto, 2001; Hakim, 2011).

Kawasan Pantai Merta Segara mempunyai kondisi 
kepadatan tutupan lamun yang beragam, ini dikarenakan ada pemanfaatan kawasan oleh masyarakat seperti tempat penambatan kapal. Selain itu, adanya aktifitas masyarakat lokal, kegiatan pariwisata, dan pembuangan limbah berpotensi memberikan pengaruh negatif terhadap komunitas padang lamun. Hal ini dapat mempengaruhi keseimbangan komunitas biota dalam habitat padang lamun. Informasi tentang kondisi biota asosiasi padang lamun masih belum banyak diteliti. Sejauh ini, hanya penelitian Istiqal et al. (2013) dan Laning (2013) yang memberikan sedikit gambaran tentang distribusi Moluska dan bulu babi di dalam kawasan. Oleh sebab itu, perlu dilakukan penelitian tentang makrozoobentos yang berasosiasi pada padang lamun di kawasan Pantai Merta Segara. Penelitian ini bertujuan untuk mengetahui asosiasi makrozoobentos dengan kepadatan padang lamun dan tipe sedimen di kawasan Pantai Merta Segara.

\section{MATERI DAN METODE}

Penelitian dilakukan di kawasan Pantai Merta Segara, Desa Sanur, Kecamatan Denpasar Selatan, Bali (Gambar 1). Secara geografis Pantai Merta Segara terletak pada posisi $08^{\circ} 42^{\prime} 14,5$ LS dan $115^{\circ} 15^{\prime} 43,5$ BT. Kawasan ini memiliki pantai yang didominasi oleh pasir putih dan terdapat tempat tambatan kapal. Waktu penelitian dilakukan pada bulan Oktober-Desember 2013.

Pengambilan sampel dilakukan pada saat air surut terendah, menggunakan metode transek kuadrat (English et al.,1994). Tiga transek tegak lurus pantai (jarak antar transek $50 \mathrm{~m}$ ) dan tiap transek dibagi menjadi 10 titik sampel dengan interval $30 \mathrm{~m}$. Pengambilan data sampel pada tiap transek menggunakan kuadrat yang dimodifikasi dengan ukuran $5 \mathrm{~m}$ x $5 \mathrm{~m}$ untuk makrozoobentos dan 0,5 m x 0,5 m untuk lamun. Kuadrat diletakkan di kanan atau kiri titik transek dengan interval $5 \mathrm{~m}$ (510-15-20-25) titik pengambilan sampel dipilih secara random dengan cara diundi (Gambar 2). Variabel yang diamati adalah presentase tutupan lamun, kepadatan makrozoobentos (di permukaan dan di dalam sedimen) dan tipe sedimen berdasarkan ukuran partikel.

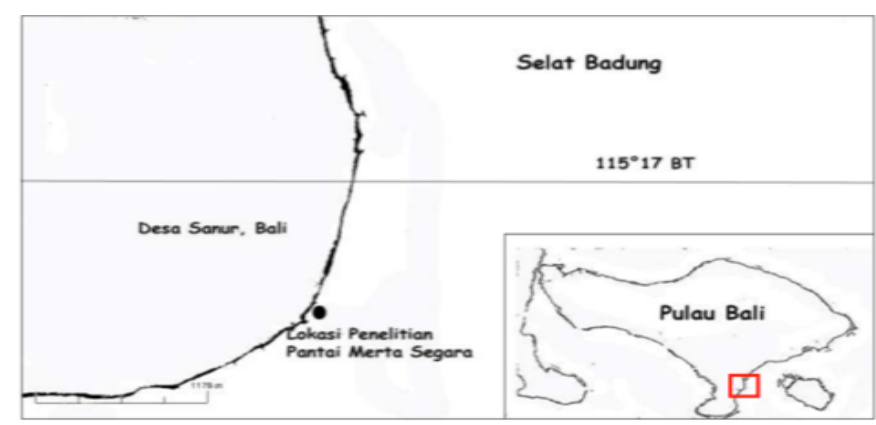

Gambar 1. Peta lokasi penelitian

Sampel makrozoobentos dibagi menjadi makrozoobentos di permukaan sedimen dan di bawah sedimen. Sampel makroozobentos yang didapatkan diawetkan dengan alkohol 70\%. Selanjutnya makrozoobentos di-

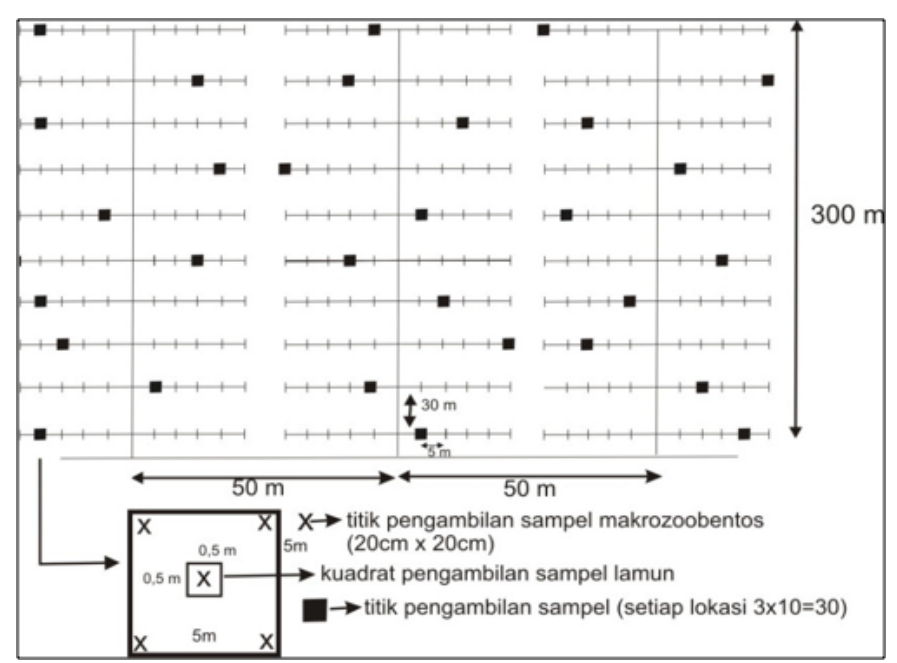

Gambar 2. Skema transek dengan kuadrat yang dimodifikasi

identifikasi menggunakan acuan dari Dharma (1988, 1992), Colin and Arneson (1995), Mather and Bennett (1994). Struktur komunitas makrozoobentos dianalisis dengan indeks diversitas Shannon-Wienner (H'), tingkat keseragaman Evenness (E) (Krebs, 1998), dan indeks dominansi Simpson (D).

Sampel lamun yang tedapat dalam kuadrat dibandingkan kepadatannya dengan menggunakan panduan Short et al., (2006). Nilai persentase tutupan lamun dihitung dengan rumus dari Saito dan Atobe (English et al., 1994).

Sampel sedimen diambil disetiap kuadrat. Selanjutnya sampel sedimen disaring dengan menggunakan saringan bertingkat sehingga sampel tersebut terbagi dalam beberapa kriteria ukuran sedimen menurut McLachlan dan Brown (2006). Berat sedimen hasil saringan bertingkat yang mewakili setiap kriteria ukuran akan disajikan dalam bentuk grafik (\% Stacked column).

\section{HASIL}

Hasil pengamatan pada Pantai Merta Segara diperoleh 47 jenis, 38 famili, 9 kelas, dan 5 filum dari 442 individu makrozoobentos. Kepadatan setiap jenis makrozoobentos dapat dilihat pada Tabel 1. Selanjutnya hasil analisis indeks diversitas, keseragaman, dominansi, kepadatan makrozoobentos, dan presentase tutupan lamun dapat di lihat selengkapnya pada Tabel 2.

Perbandingan makrozoobentos (Kelas) di permukaan dan di dalam sedimen dapat dilihat pada Gambar 3 . Pada permukaan sedimen ditemukan 7 kelas yaitu Asteroidea, Holothuroidea, Ophiuroidea, Echinoidea, Gastropoda, Bivalvia, dan Malacostraca dengan kelas yang paling banyak ditemukan yaitu kelas Gastropoda. Sedangkan di dalam sedimen ditemukan 5 kelas yaitu Bivalvia, Gastropoda, Malacostraca, Polychaeta, dan Sipunculidae dengan kelas Malacostraca yang paling banyak ditemukan. Kelas yang dapat ditemukan di permukaan dan dalam sedimen antara lain Gastropoda, Bivalvia, dan Malacostraca. 
Tabel 1. Kepadatan jenis makrozoobentos (ind/ha) di Pantai Merta Segara

\begin{tabular}{|c|c|c|c|c|}
\hline Filum & Kelas & Famili & Jenis & Rata-rata (ind/ha) \\
\hline \multirow[t]{17}{*}{ Echinodermata } & \multirow[t]{7}{*}{ Asteroidea } & \multirow[t]{3}{*}{ Oreasteridae } & Protoreaster nodusus & 146 \\
\hline & & & Pentaceraster regulus & 106 \\
\hline & & & Culcita novaeguinea & 40 \\
\hline & & Archasteridae & Archaster typicus & 13 \\
\hline & & \multirow{3}{*}{ Ophidiasteridae } & Linckia sp. & 80 \\
\hline & & & Linckia laevigata & 13 \\
\hline & & & Nardoa tuberculata & 13 \\
\hline & \multirow[t]{6}{*}{ Echinoidea } & \multirow[t]{3}{*}{ Diadematidae } & Diadema savignyi & 13 \\
\hline & & & Diadema setosum & 40 \\
\hline & & & Echinothrix calamaris & 80 \\
\hline & & Toxopneustidae & Tripneustes gratilla & 120 \\
\hline & & Echinometridae & Echinometra mathaei & 26 \\
\hline & & Loveniidae & Echinocardium sp. & 40 \\
\hline & \multirow[t]{2}{*}{ Holothurioidea } & Synaptidae & Synaptula sp. & 453 \\
\hline & & Holothuridae & Holothuria atra & 13 \\
\hline & \multirow[t]{2}{*}{ Ophiuroidea } & Ophiodermatidae & Ophiarachna incrassata & 226 \\
\hline & & Ophiocomidae & Ophiarthum pictum & 320 \\
\hline \multirow[t]{11}{*}{ Mollusca } & \multirow[t]{10}{*}{ Gastropoda } & Nassariidae & Nassarius corronatus & 160 \\
\hline & & Volutidae & Cymbiola vespertillo & 40 \\
\hline & & Naticidae & Polinices flemingana & 120 \\
\hline & & Strombidae & Lambis crocata & 26 \\
\hline & & Cerithiidae & Cerithium aluco & 26 \\
\hline & & Terebridae & Terebra sp. & 13 \\
\hline & & Pleurobranchidae & Pleurobranchus forskalii & 93 \\
\hline & & Conidae & Conus virgo & 66 \\
\hline & & Cypraeidae & Cypraea tigris & 13 \\
\hline & & Phyllidiidae & Phyllidiela nigra & 53 \\
\hline & Bivalvia & Cardiidae & Vepricardium sinense & 120 \\
\hline \multirow[t]{14}{*}{ Anthropoda } & \multirow[t]{14}{*}{ Malacostraca } & Portunidae & Thalamita sp. & 533 \\
\hline & & Xanthidae & Etisus sp. & 200 \\
\hline & & \multirow[t]{2}{*}{ Pilumnidae } & Glabropilumnus sp. & 360 \\
\hline & & & Pilumnus sp. & 40 \\
\hline & & Grapsidae & Pachygrapsus sp. & 26 \\
\hline & & \multirow[t]{2}{*}{ Callappidae } & Matuta sp. & 13 \\
\hline & & & Calappa sp. & 26 \\
\hline & & Leucosiidae & Philyra sp. & 40 \\
\hline & & \multirow[t]{2}{*}{ Majidae } & Camposcia sp. & 13 \\
\hline & & & Hyastenus sp. & 26 \\
\hline & & Alpheidae & Alpheus sp. & 213 \\
\hline & & Processidae & Nikoides sp. & 506 \\
\hline & & Gonodactylusidae & Gonodactylus sp. & 53 \\
\hline & & Nebaliidae & Nebalia sp. & $\begin{array}{l}30 \\
13\end{array}$ \\
\hline \multirow[t]{3}{*}{ Annelida } & \multirow[t]{3}{*}{ Polychaeta } & Amphinomidae & Eurythoe sp. & 586 \\
\hline & & Eunicidae & Eunice sp. & 173 \\
\hline & & Polynoidae & Harmothoe sp. & 146 \\
\hline \multirow{2}{*}{ Sipuncula } & \multirow{2}{*}{ Sipunculidea } & Sipunculidae & Sipunculus sp. & 413 \\
\hline & & Themistidae & Themiste sp. & 26 \\
\hline
\end{tabular}

Tabel 2. Jumlah individu, jumlah jenis, indeks diversitas, keseragaman, dominansi, kepadatan makrozoobentos $( \pm \mathrm{SD})$, dan presentase tutupan lamun $( \pm \mathrm{SD})$

\begin{tabular}{lc}
\hline Jumlah individu & 442 \\
Jumlah jenis makrozoobentos & 47 \\
Indeks Diversitas (H') & 4,7 \\
Keseragaman (E) & 0,85 \\
Dominansi (C) & 0,05 \\
Kepadatan makrozoobentos (ind/ha) & $5893 \pm 3594$ \\
Presentase tutupan lamun (\%) & $51,1 \pm 32,24$ \\
\hline
\end{tabular}

Asosiasi makrozoobentos dengan tutupan lamun di pantai Merta Segara, menunjukkan bahwa kepadatan makrozoobentos memiliki korelasi positif ( $\left.\mathrm{R}^{2}: 0,095\right)$

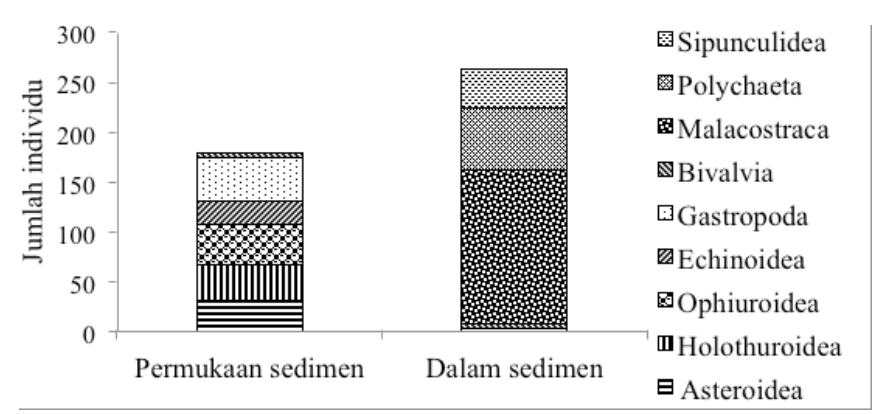

Gambar 3. Perbandingan makrozoobentos di permukaan dan dalam sedimen.

dengan tutupan lamun (Gambar 4A). Presentase tutupan lamun kawasan Pantai Merta Segara sebesar 50,1 \%. 

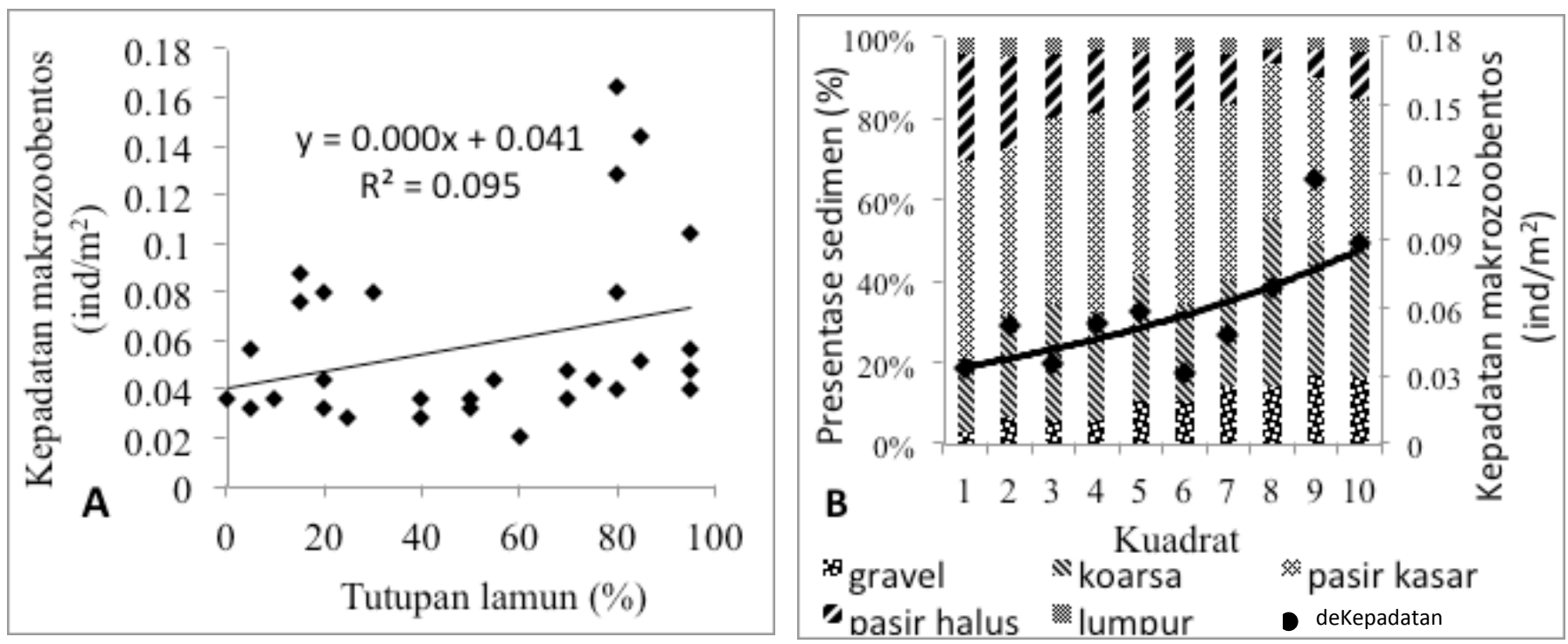

Gambar 4. A: Hubungan tutupan lamun dengan kepadatan makrozoobentos (ind $/ \mathrm{m}^{2}$ ), B: sebaran makrozoobentos berdasarkan ratarata kepadatan (ind $/ \mathrm{m}^{2}$ ) dan presentase sedimen berdasarkan rata-rata ukuran partikel (tipe substrat)

Tipe sedimen pada Pantai Merta Segara didominansi dengan pasir kasar dan koarsa. Sebaran kepadatan makrozoobentos mempunyai pola yang meningkat dari tepi ke arah tubir seiring dengan peningkatan tipe sedimen gravel (Gambar 4).

\section{PEMBAHASAN}

Nilai indeks diversitas (H') di Pantai Merta Segara diperoleh 4,7 dapat dikategorikan keanekaragaman tinggi. Nilai indeks keseragaman (E) mendekati 1, ini menunjukkan bahwa keseragaman tinggi dan memiliki penyebaran individu yang merata. Nilai indeks dominansi (D) dibawah o,50 menunjukkan dominansi rendah dan tidak terdapat jenis yang mendominansi. Tingginya nilai indeks diversitas ( $\left.\mathrm{H}^{\prime}\right)$ mengindikasikan bahwa komunitas makrozoobentos masih stabil dan belum ada pengaruh signifikan dari aktifitas yang ada. Indeks diversitas ini juga dapat memberikan gambaran tentang kondisi perairan di Pantai Merta Segara. Menurut Wijayanti (2007), beragamnya makrozoobentos yang ditemukan pada suatu perairan dapat menggambarkan kondisi perairan tersebut. Sedangkan Iswanti et al (2012), menyatakan bahwa kondisi perairan yang baik memiliki nilai indeks diversitas yang tinggi $\left(\mathrm{H}^{\prime}=>3\right)$ dengan penyebaran jenis yang merata serta tidak adanya jenis yang mendominansi.

Bila dibandingkan hasil penelitian makrozoobentos pada padang lamun di kawasan lain dengan jumlah jenis yang ditemukan di Pantai Merta Segara masih tergolong sedikit. Di Pantai Geger Kecamatan Kuta Selatan ditemukan 63 jenis (Huda, 2005), sedangkan perairan Pulau Bonebatang ditemukan 60 jenis (Mattewakkang, 2013). Tetapi bila dibandingkan dengan jumlah jenis makrozoobentos yang ditemukan di Pantai Pererenan Kabupaten Badung 17 jenis (Wiratmini, 2008) dan perairan Kuala Gigieng Kabupaten Aceh Besar 12 jenis (Fadli et al., 2012), jumlah jenis di Pantai Merta Segara masih tergolong beragam. Perbedaan jumlah jenis dalam setiap perairan dapat disebabkan karena faktor lingkungan, seperti kondisi kepadatan tutupan lamun, tipe sedimen, aktifitas masyarakat dan bahan pencemar (Nybakken, 1988).

Kepadatan masing-masing jenis makrozoobentos (ind/ ha) berkisar dari 13-586 ind/ha. Jenis yang paling banyak ditemukan yaitu Eurythoe sp., sedangkan Archaster typicus, Linckia laevigata, Nardoa tuberculata, Diadema savignyi, Holothuria atra, Terebra sp., Cypraea tigris, Matuta sp., Camposcia sp., Nebalia sp. termasuk jenis yang jarang ditemukan. Menurut Jurnadi dan Murwani (2004) melimpahnya jenis Eurythoe sp. (Polychaeta) di perairan pantai dikarenakan penyebarannya mengelompok dan seragam, tipe substrat yang berpasir, mampu beradaptasi terhadap perubahan lingkungan, serta tingginya kandungan bahan organik di bawah sedimen. Jenis makrozoobentos yang jarang ditemukan diduga dipengaruhi oleh adanya faktor biologi (organisme), fisik (suhu, tekstur sedimen, salinitas, kandungan bahan organik di sedimen), kimia $(\mathrm{pH}$, $\mathrm{O} 2, \mathrm{CO} 2$ ) dan aktifitas pemanfaatan yang mengarah eksploitasi (Odum, 1993; Patang, 2012).

Makrozoobentos dari kelas Malacostraca banyak ditemukan di Pantai Merta Segara terutama di dalam sedimen. Kelas ini ditemukan melimbah karena dapat melakukan adaptasi terhadap daerah pasang surut dengan menggali sedimen sampai kedalaman tertentu yang tidak lagi dipengaruhi oleh hempasan gelombang dan paparan cahaya matahari (Nybakken, 1988). Menurut Taqwa (2010), makrozoobentos yang berada di dalam sedimen mempunyai peran penting menjaga keseimbangan ekosistem, hal ini disebabkan karena makrozoobentos yang membuat lubang pada sedimen memberikan 
peningkatan unsur hara dan oksigen dalam sedimen. Melimpahnya makrozoobentos di dalam sedimen akan memberikan ketersediaan unsur hara yang cukup bagi lamun dan menggambarkan minimnya kandungan bahan anorganik di dalam sedimen (Ira, 2011).

Makrozoobentos yang banyak ditemukan pada permukaan sedimen adalah makrozoobentos dari kelas Gastropoda, hal ini mengindikasikan bahwa kelas tersebut mendominansi asosiasi di kawasan padang lamun tersebut. Kelas Gastropoda merupakan makrozoobentos epifauna yang memanfaatkan lamun secara langsung sebagai tempat berlindung dari kecepatan arus yang kuat dan predator (Hitalessy, 2015). Beberapa jenis Moluska menggunakan daun lamun sebagai tempat untuk menaruh telur. Selain itu, bahan organik berupa destritus pada kawasan padang lamun, menjadi sumber makanan utama bagi oganisme destritus feeder seperti Gastropoda (Syari, 2005).

Asosiasi kepadatan makrozoobetos dengan tutupan lamun menunjukkan asosiasi yang positif yaitu peningkatan tutupan lamun diikuti dengan peningkatan kepadatan makrozoobentos. Presentase tutupan lamun diperoleh 50,1 \% yang mengindikasikan bahwa kerapatan padang lamun kawasan tersebut mempunyai kerapatan sedang. Padang lamun menjadi habitat yang sangat mendukung kelangsungan hidup dari makrozoobentos. Makrozoobentos dapat memanfaatkan lamun sebagai tempat berlindung, memijah, daerah asuhan, dan mencari makan. Menurut Ira (2011) kerapatan lamun yang tinggi meningkatkan total bahan organik sehingga dapat menambah kelimpahan makrozoobentos yang berasosiasi di dalamnya. Sedangkan Irawan (2003) menyatakan bahwa kepadatan tutupan lamun berperan terhadap peningkatan keanekaragaman makrozoobentos.

Lamun yang mempunyai daun yang panjang dapat menjadi jalan bermigrasi bagi makrozoobentos dari sedimen ke daun lamun. Beberapa kelas makrozoobentos dapat memanfaatkan detritus yang berasal dari tumbuhan lamun yang mati, plankton, bakteri, dan bahan organik lain yang terendap pada butiran pasir dan lumpur sebagai bahan makanannya (Ira, 2011). Produktivitas lamun memberikan kontribusi yang bervariasi di perairan hal ini disebabkan adanya perbedaan biomassa, pertumbuhan, dan kepadatan dari masing-masing jenis lamun. Jenis lamun seperti Enhalus acoroides, Thalassia hemprichii, dan Cymodecea rotendata diketahui mempunyai produktivitas daun dan rhizome yang tinggi (Supriadi et al., 2012).

Tipe sedimen pada Pantai Merta Segara didominansi oleh pasir kasar dan koarsa. Hal ini menunjukkan bahwa aliran arus di kawasan Merta Segara relatif sedang. Adaptasi organisme makrozoobentos pada sedimen berpasir dapat dilakukan dengan menggali lubang untuk berlindung dari ombak dan paparan cahaya matahari seperti dari Filum Annelida, Moluska, dan Athropoda. Tipe substrat berpasir mempunyai ukuran kecil yang mempengaruhi penyebaran organisme dan kelimpahannya, hal ini disebabkan karena mudah digali dan mempunyai retensi air tinggi. Retensi air yang berpengaruh terhadap kehidupan makrozoobentos, ini disebabkan karena dengan gaya kapiler yang dimiliki butiran pasir dapat lebih banyak menampung air saat terjadi pasang surut (Nyabakken, 1988). Keberadaan dan komposisi makrozoobentos pada dalam sedimen dapat menunjukkan perubahan kondisi lingkungan yang terjadi pada kawasan tersebut (Indarmawan dan Manan, 2011).

Bila dilihat dari tepi ke arah tubir, pola yang terlihat pada kepadatan jenis makrozoobentos mengalami peningkatan. Hal ini diikuti dengan peningkatan tipe sedimen gravel dari tepi ke arah tubir yang meningkat walaupun tidak terlalu signifikan. Hal ini menunjukkan terjadinya asosiasi makrozoobentos dengan sedimen tipe gravel. Tipe sedimen gravel menyediakan tempat berlindung untuk makrozoobentos dari gerakan arus. Arus yang kuat atau meningkat dari tepi ketubir juga mempengaruhi sebaran makrozoobentos dan menyebabkan terjadinya penggelompokan hewan bentik berdasarkan tipe sedimennya (Fadli et al., 2012). Perbedaan jenis makrozoobentos antar kawasan dapat dipengaruhi oleh kandungan bahan organik sedimen dan faktor fisika-kimia perairan seperti kekeruhan, kecepatan arus, dan kadar oksigen terlarut (Hakim, 2011).

\section{SIMPULAN}

Kondisi komunitas makrozoobentos di padang lamun di Pantai Merta Segara masih tergolong stabil (H’: 4,7, E: 0,85, C: 0,05). Sebaran makrozoobentos menunjukkan korelasi positif dengan kepadatan tutupan lamun dan tipe sedimen gravel.

\section{KEPUSTAKAAN}

Arifin. dan J. Jompa. 2005. Studi Kondisi dan Potensi Ekosistem Padang Lamun Sebagai Daerah Asuhan Biota Laut.

J. Ilmu-ilmu Perairan dan Perikanan Indonesia 12(2):73-79.

Colin, P. L. and A. C. Anerson. 1995. Tropical Pacific Invertebrates. Coral Reef Press. USA.

Dharma, B. 1988. Siput dan Kerang Indonesia Indonesian Shell. PT Sarana Graha. Jakarta.

1992. Siput dan Kerang Indonesia Indonesian Shell II. PT Sarana Graha. Jakata.

English, S., C. Wilkinson, and V.J. Baker. 1994. Survey Manual for Tropical Marine Resources. ASEAN-Australia Marine Project. Australia.

Fadli, N., I. Setiawan dan N. Fadhilah. 2012. Keragaman Makrozoobentos di Perairan Kuala Gigieng Kabupaten Aceh Besar. J. Depik (1):45-52.

Hakim, I. I. A. 2011. Fauna Makrobentik Substrat Lunak Di Perairan Pelabuhan Tanjung Mas Semarang, Jawa Tengah. Oseanologi dan Limnologi di Indonesia 3(1):171-189.

Hitalessy, R. B., A. S. Leksono. Dan E. Y. Herawati. 2015. Struktur Komunitas Dan Asosiasi Gastropoda Dengan Tumbuhan Lamun di Perairan Pesisir Lamongan Jawa Timur. J. Pal. 6(1):64-73.

Huda, Q. 2005. Kondisi Pantai Geger Desa Bualu Kecamatan Kuta Selatan Dilihat dari Komunitas Padang Lamun dan Makrozoobentos Serta Implikasinya dalam Pengelolaan Pantai. 
Jurusan Biologi Fakultas Matematika dan Ilmu Pengetahuan Alam. Universitas Udayana. (Skripsi).

Indarmawan, T. dan A. Manan. 2011. Pemantauan Lingkungan Estuaria Perancak Berdasarkan Sebaran Makrzoobenthos. J. Ilmiah Perikanan dan Kelautan 3 (2):215-220.

Ira. 2011. Keterkaitan Padang Lamun Sebagai Pemerangkap dan Penghasil Bahan Organik dengan Struktur Komunitas Makrozoobentos di Perairan Pulau Barrang Lompo. Program Studi Ilmu Kelautan Program Pascasarjana. Institut Pertanian Bogor. (Tesis).

Irawan, A. 2003. Asosiasi Makrozoobentos Berdasarkan Letak Padang Lamun di Estuaria Bontang Kuala Kota Bontang Kalimantan Timur. Program Studi Ilmu Kelautan Program Pascasarjana. Institut Pertanian Bogor. (Tesis).

Istiqal, B. A., D. S. Yusup. dan N. M. Suartini. 2013. Distribusi Horizontal Moluska di Kawasan Padang Lamun Pantai Merta Segara Sanur, Denpasar. J. Biol. XVII(1): 10-14.

Iswanti, S., S. Ngabekt. dan N. K .T. Martuti. 2012. Distribusi dan Keanekaragaman Jenis Makrozoobentos di Sungai Damar Desa Weleri Kabupaten Kendal. J. Life Science 1(2):86-93.

Junardi. dan S. Murwani. 2004. Keanekaragaman dan Pola Penyebaran Genus Cacing Laut Polychaeta di Pantai Timur, Lampung Selatan. J. Sains Tek. 10(1):58-64.

Krebs CJ. 1989. Ecological Methodology. Harper and Row Publisher. New York. $694 \mathrm{p}$

Laning, T. H. 2013. Asosiasi Bulu Babi (Echinoidea) di Padang Lamun (Seagrass Beds) Pantai Merta Segara, Kelurahan Sanur, Denpasar Selatan, Provinsi Bali. Jurusan Biologi Fakultas Matematika dan Ilmu Pengetahuan Alam. Universitas Udayana. (Skripsi).

Marmita, R., R. Siahaan., R. Koneri. Dan M. L. Langoy. 2013. Makrozoobentos Sebagai Indicator Biologis Dalam Menentukan Kualitas Air Sungai Ranoyapo, Minahasa Selatan, Sulawesi Utara. J. Ilmiah Sains 13(1):58-61.

Mather, P. and I. Bennett. 1994. A Guide To The Geology, Flora And Fauna Of The Great Barrier Reef. Surrey Beatty and Sons Pty Limited. Australia.

Mattewakkang. 2013. Inventarisasi Makrozoobentos Pada Berbagai Jenis Lamun di Pulau Bonebatang. Jurusan Ilmu Kelautan. Fakultas Ilmu Kelautan Dan Perikanan. Universitas Hasanuddin. (Skripsi).
Mclachlan, A dan A. C. Brown. 2006. The Ecology of Sandy Shore. Elsevier Inc. USA.

Nybakken, J. W. 1988. Ekologi Laut Suatu Pendekatan Ekolgi. PT. Gramedia. Jakarta.

Odum, E. P. 1993. Dasar-dasar Ekologi. Edisi Ketiga. Penerjemah Ir. Tjahjono Samingan, M.Sc. Gadjah Mada University Press. Yogyakarta.

Patang, F. 2012. Makrozoobentos yang Bernilai Ekonomis di Pesisir Pantai Lamaru Balikpapan. J. Mulawarman Scientific 11(2):229-235.

Ruswahyuni. 2008. Struktur Komunitas Makrozoobentos yang Berasosiasi dengan Lamun pada Pantai Berpasir di Jepara. J. Saintek Perikanan 3(2):33-36.

Short, F.T., L. J. McKenzie., R. G. Coles., K. P. Vidler. and J. L. Gaeckle. 2006. SeagrassNet Manual for Scientific Monitoring of Seagrass Habitat, Worldwide Edition. University of New Hampshire Publication. 75 pp.

Sudaryanto, A. 2001. Stuktur Komunitas Makrozoobentos Dan Kondisi Fisika Kimiawi Sedimen Di Perairan Donan, CilacapJawa Tengah. J. Teknologi Lingkungan 2(2):119-123.

Supriadi., R. F. Kaswadji., D. G. Bengen. dan M. Hutomo. 2012. Produktivitas Komunitas Lamun Di Pulau Barrang Lompo Makassar. J. Akuatik 3(2): 159-168.

Syari, I. A. 2005. Asosiasi Gastropoda di Ekosistem Padang Lamun Perairan Pulau Lepar Provinsi Kepulauan Bangka Belitung. Departemen Ilmu dan Teknologi Kelautan. Fakultas Perikanan dan Ilmu Kelautan. Institut Pertanian Bogor. (Skripsi).

Taqwa, A. 2010. Analisis Produktivitas Fitoplankton dan Struktur Komunitas Fauna Makrozoobentos Berdasarkan Kerapatan Mangrove di Kawasan Konservasi Mangrove dan Bekantan Kota Tarakan, Kalimantan Timur. Program Studi Manajemen Sumberdaya Pantai. Program Pascasarjana. Universitas Diponogoro Semarang. (Tesis).

Wijayanti, H. 2007. Kajian Kualitas Perairan di Pantai Kota Bandar Lampung Berdasarkan Komunitas Hewan Makrozoobentos. Program Magister Manajemen Sumberdaya Pantai. Program Pascasarjana. Universitas Diponogoro Semarang. (Tesis).

Wiratmini, N. I., J. Wiryatno. dan A. A. G. R. Dalem. 2008. Makrozoobentos Pantai Pererenan (Kabupaten Badung): Jenis, Status dan Manfaatnya Bagi Masyarakat. J. Bumi Lestari 8(2):176-179. 